\title{
ANALISIS RISIKO KEJADIAN DIABETES MELITUS PADA PASIEN TB DI WILAYAH KERJA PUSKESMAS KAMONJI KOTA PALU
}

\author{
Risk Analysis of Diabetes Mellitus in TB Patients in the Working Area of Kamonji Public \\ Health Center in Palu City
}

\author{
Muh. Jusman Rau ${ }^{*}$, Nur Mifta Huldjannah ${ }^{2}$ \\ Jurusan Epidemiologi, Fakultas Kesehatan Masyarakat, Universitas Tadulako, Indonesia
}

*Korespondensi: jusmanepid06@gmail.com

\begin{abstract}
ABSTRAK
Negara yang memiliki beban TB seperti Indonesia akan terkena dampak peningkatan kormobid Diabetes Melitus, sehingga Indonesia mempunyai beban ganda dalam penyelesaian penyakit menular dan penyakit tidak menular. Kota Palu merupakan salah satu Kabupaten/Kota yang memiliki kasus TB tertinggi di Sulawesi Tengah sebanyak 693 kasus dan kasus Diabetes Melitus di Kota Palu sebanyak 5.824 kasus. Kejadian TB-DM di Puskesmas Kamonji dilaporkan berjumlah 18 kasus. Tujuan penelitian ini untuk menganalisis faktor risiko kejadian TB-DM di wilayah kerja Puskesmas Kamonji Kota Palu. Penelitian ini menggunakan desain penelitian case-control serta sampel menggunakan teknik Purposive Sampling yang berjumlah 64 responden dengan perbandingan 1:3. Analisis data dilakukan secara univariat, bivariat dan multivariat. Hasil penelitian menunjukkan bahwa IMT $(\mathrm{OR}=0,227)$ merupakan faktor protektif. Sedangkan Umur $(\mathrm{OR}=4,012)$, Riwayat Diabetes Melitus $(\mathrm{OR}=16,465)$ dan Perilaku Merokok $(\mathrm{OR}=3,800)$ merupakan faktor risiko dari kejadian TBDM di wilayah kerja Puskesmas Kamonji. Determinan TB-DM yaitu Riwayat Diabetes Melitus ( $p$ 0,000). Upaya pencegahan untuk menekan kejadian TB-DM yaitu melakukan screening PTM secara teratur, pengaturan pola makan yang tepat, melakukan aktivitas fisik dan meningkatkan kesadaran perilaku merokok yang baik.
\end{abstract}

Kata kunci : Diabetes melitus, faktor risiko, tuberkulosis

\section{ABSTRACT}

Countries that have a burden of TB such as Indonesia will be affected by the increase in comorbid Diabetes Mellitus so that Indonesia has a double burden in solving infectious and noncommunicable diseases. Palu City is one of the subdistrict/cities with the highest TB cases in Central Sulawesi with 693 cases and Diabetes Mellitus cases in Palu City with 5.824 cases. TB-DM incidents at Kamonji Public Health Center were reported to be 18 cases. This research aims to analyze the risk factors for TB-DM in the working area of Kamonji Public Health Center in Palu City. This research used a case-control research design and the sample totaled 64 respondents with a ratio of 1:3 selected using a purposive sampling technique. Data were analyzed using univariate, bivariate, and multivariate methods. The results of the research show that IMT $(O R=0.227)$ is a protective factor, age $(O R=4.012)$, history of diabetes mellitus $(O R=16.465)$ and smoking behavior $(O R=3.800)$ are the risk factors for the incidence of TB-DM in the working area of Kamonji Public Health Center. The determinant of TB-DM is the history of diabetes mellitus ( $p$ 0.000). Prevention efforts to reduce the incidence of TB-DM are conducting regular PTM screening, setting a proper diet, doing physical activity, and increasing awareness of good smoking behavior

Keywords: Diabetes mellitus, risk factor, tuberculosis 


\section{PENDAHULUAN}

Penyakit Tuberkulosis (TB) masih menjadi beban kesehatan masyarakat semenjak ditetapkannya TB sebagai global emergency oleh WHO pada tahun 1992. Berbagai macam upaya penanggulangan dan pencegahan yang dilakukan oleh berbagai pihak, baik skala nasional maupun internasional (Chritianto A, 2018). Salah satunya, pada era SDG'S (Sustainable Development Goals) WHO merancang program "END TB". Tujuan dari program END-TB yakni untuk mengakhiri epidemi TB di seluruh dunia (WHO, 2015).

Semenjak program END-TB diberlakukan, penyakit TB pun masih menjadi salah satu dari 10 penyebab kematian utama di seluruh dunia dan penyebab pertama kematian akibat satu agen infeksi sebelum HIV/AIDS. WHO menyatakan bahwa setengah penduduk dunia mengidap penyakit ini, dimana sebagian besar berada di negara berkembang diantara tahun 2000 sampai 2018 angka mortality rate dari penyakit TBC sebesar 42\% (WHO, 2019).

Kemenkes RI mencatat, pada tahun 2017 jumlah kasus TB di Indonesia sebanyak 446.732 kasus, lalu pada tahun 2018 mengalami peningkatan menjadi 566.623 kasus. Sulawesi Tengah termasuk salah satu Provinsi yang telah dilaporkan terkait adanya kasus TB, berdasarkan estimasi prevalence dari Case Detection Rate (CDR) tahun 2018 tercatat sekitar 417/100.000 penduduk menderita TB semua tipe. Kota Palu merupakan salah satu Kabupaten/Kota yang melaporkan peningkatan kasus TB BTA+ setiap tahunnya. Tercatat jumlah kasus baru BTA+ yang ditemukan pada tahun 2017 sebanyak 467 kasus, angka tersebut meningkat jika dibandingkan dengan jumlah kasus tahun 2016 yaitu 439 kasus (Kemkes RI, 2019), (Dinkes Sulteng, 2019), (Dinkes Palu, 2018).

Setiap hari jumlah kasus pasien TB terus bertambah, diperkirakan setiap 30 detik terdapat satu orang yang tertular dan setiap jamnya ada 812 orang meninggal akibat TB (Sembiring SPK, 2019). Menurut WHO, diperkirakan 5-10\% dari 1.7 miliar orang yang terinfeksi $\mathrm{TB}$ akan mengalami pengembangan penyakit selama hidupnya. Namun terdapat beberapa kriteria populasi yang memiliki risiko lebih besar untuk terinfeksi TB salah satunya penderita Diabetes Melitus (DM) (Prameyllawati DM dkk, 2019).

Diabetes Melitus (DM) merupakan penyakit metabolisme yang dikarenakan meningkatnya kadar gula darah (glukosa) seseorang di dalam tubuh yang tinggi melebihi batas normal (hyperglycemia) akibat dari penurunan sekresi insulin oleh sel beta pankreas dan atau fungsi insulin (resistan insulin) (Kemkes RI, 2015). Kejadian Diabetes Melitus disebabkan perubahan gaya hidup, tingginya angka obesitas, dan kurangnya aktivitas fisik yang pada umumnya terjadi di negara-negara yang mulai mengalami industrialisasi (Hoa NB dkk, 2018). Hal ini juga merupakan salah satu penyebab angka tuberkulosis terus mengalami peningkatan dan sulit untuk diberantas. Sebab 
banyak pasien Diabetes Melitus yang mudah terkena tuberkulosis aktif (Sembiring SPK, 2019).

Kormorbid TB-DM merupakan timbulnya kedua penyakit pada individu sehingga orang tersebut dapat menderita Diabetes Melitus terlebih dahulu kemudian terinfeksi TB ataupun sebaliknya (Prameyllawati DM dkk, 2019). Meskipun TB lebih erat kaitannya dengan penyakit defisiensi imun lainnya seperti HIV, tetapi jumlah orang dengan diabetes jauh lebih besar. Hal tersebut membuat Diabetes Melitus merupakan faktor risiko yang lebih signifikan untuk TB pada tingkat populasi (Rohman $\mathrm{H}$, 2018).

Berdasarkan hasil studi pendahuluan yang dilakukan oleh peneliti di salah satu Puskesmas di Kota Palu yaitu Puskesmas Kamonji. Pasien TB-DM terus mengalami peningkatan, pada tahun 2019 tercatat 9 pasien TB-DM sedangkan pada bulan Januari sampai bulan Juni 2020 tercatat sebanyak 18 penderita. Berdasarkan permasalahan tersebut maka peneliti tertarik untuk menganalisis faktor risiko kejadian TBDM di wilayah kerja Puskesmas Kamonji Kota Palu.

\section{BAHAN DAN METODE}

Penelitian ini adalah penelitian kuantitatif dengan pendekatan survey analitik, dengan desain Case Control Study. Penelitian ini dilaksanakan pada bulan Agustus sampai bulan September 2020 di wilayah kerja Puskesmas
Kamonji. Populasi kasus dalam penelitan ini adalah semua penderita TB-DM yang berdomisili di wilayah kerja Puskesmas Kamonji Palu sebanyak 18 orang. Sedangkan populasi kontrol adalah semua penderita TB BTA (+) yang berdomisili di wilayah kerja Puskesmas Kamonji Palu sebanyak 88 orang. Dalam menentukan ukuran sampel, peneliti menggunakan rumus Slovin dengan perbandingan 1:3 sehingga jumlah sampel menjadi 64 responden terdiri dari 16 orang kelompok kasus dan 48 orang kelompok kontrol. Teknik pengambilan sampel yaitu secara Purposive sampling. Adapun kriteria yang digunakan yaitu penderita TB-DM yang telah didiagnosa oleh tenaga kesehatan yang bertempat tinggal di wilayah kerja Puskesmas Kamonji Palu, dapat berkomunikasi dengan baik dan bersedia menjadi responden.

Pengumpulan data menggunakan data primer dan sekunder. Analisis data dilakukan dengan menggunakan 3 cara yaitu analisis univariat, bivariat dan multivariat.

\section{HASIL}

\section{Analisis Univariat}

Berdasarkan Tabel 1, distribusi responden berdasarkan kelompok umur paling banyak pada kelompok umur 50-58 tahun sebanyak 13 orang $(20,3 \%)$. Karakteristik jenis kelamin responden paling banyak dengan jenis kelamin laki-laki yaitu 36 orang $(56,2 \%)$. Berdasarkan status pendidikan, responden dengan pendidikan 
SMA/Sederajat memiliki jumlah terbesar yaitu

41 orang $(64,1 \%)$. Berdasarkan status pekerjaan responden paling banyak memiliki status pekerjaan wiraswasta sebanyak 21 orang $(32,8 \%)$. Berdasarkan status IMT, sebagian besar respon memiliki IMT underweight sebanyak 37 orang $(67,8 \%)$. Berdasarkan status riwayat Diabetes Melitus sebagian besar responden tidak memiliki riwayat Diabetes Melitus dalam anggota keluarga sebanyak 41 orang $(64,1 \%)$. Perilaku merokok yang paling banyak dimiliki responden adalah perilaku merokok berisiko rendah sebanyak 46 orang $(71,9 \%)$.

\section{Analisis Bivariat}

Berdasarkan Tabel 2, sebagian besar responden mengalami TB-DM yang berumur $\geq$ 45 tahun sebanyak 11 orang $(68,8 \%)$ sedangkan responden mengalami TB tanpa Diabetes Melitus yang berumur $\geq 45$ tahun sebanyak 17 orang $(35,4 \%)$. Berdasarkan analisis uji OR menunjukkan bahwa seseorang yang berumur $\geq$ 45 tahun akan berisiko 4,012 kali lebih besar mengalami TB-DM dibandingkan dengan orang yang berumur $<45$ tahun. Hal ini terlihat dari nilai $\mathrm{OR}=4,012(\mathrm{CI} 95 \%=$ 1,195-13,472).

Berdasarkan Tabel 2, dari 16 responden yang mengalami TB-DM, sebagian besar memiliki status IMT normal sebanyak 11 orang $(68,8 \%)$ dan hanya 5 orang $(31,2 \%)$ yang memiliki status IMT underweight sedangkan responden yang mengalami TB tanpa Diabetes Melitus sebagian besar memiliki status IMT underweight sebanyak 32 orang $(66,7 \%)$ dibandingkan dengan responden yang memiliki status IMT normal sebanyak 16 orang $(33,3 \%)$. Sehingga variabel IMT merupakan faktor protektif dari penelitian ini, hal ini dikarenkan nilai OR sebesar 0,227 (CI 95\% =0,067-0776).

Berdasarkan Tabel 2, dari 16 responden yang mengalami TB-DM sebagian besar memiliki riwayat Diabetes Melitus sebanyak 13 orang $(81,2 \%)$ sedangkan responden yang mengalami TB tanpa Diabetes Melitus sebagian besar tidak memiliki riwayat Diabetes Melitus sebanyak 38 orang $(79,2 \%)$. Berdasarkan uji OR menunjukkan bahwa seseorang yang memiliki orang tua yang mengalami Diabetes Melitus berisiko 16,467 kali lebih besar mengalami TBDM dibandingkan dengan orang yang tidak memiliki riwayat diabetes melitus. Hal ini terlihat dari nilai $\mathrm{OR}=16,467(\mathrm{CI} 95 \%=3,918$ $-69,202)$.

Berdasarkan Tabel 2, menunujukkan bahwa dari 16 responden yang mengalami TBDM, ditemukan masing-masing 8 orang $(50,0 \%)$ yang memiliki perilaku merokok risiko tinggi sedangkan responden yang mengalami TB tanpa Diabetes Melitus, sebagian besar memiliki perilaku merokok yang risiko rendah sebanyak 38 orang (79,2\%). Berdasarkan uji OR menunjukkan bahwa seseorang yang memiliki perilaku merokok yang risiko tinggi akan berisiko 3,800 kali lebih besar mengalami TB- 
DM dibandingkan dengan orang yang memiliki perilaku merokok risiko rendah. Hal ini telihat dari nilai OR $=3,800($ CI 95\% $=1,142-12,646)$.

Tabel 1. Karakteristik Responden

\begin{tabular}{|c|c|c|}
\hline Karakteristik & n & $\%$ \\
\hline \multicolumn{3}{|l|}{ Umur } \\
\hline $14-22$ & 8 & 12,5 \\
\hline $23-31$ & 12 & 18,8 \\
\hline $32-40$ & 12 & 18,8 \\
\hline $41-49$ & 11 & 17,1 \\
\hline $50-58$ & 13 & 20,3 \\
\hline $59-67$ & 5 & 7,9 \\
\hline $68-76$ & 3 & 4,6 \\
\hline \multicolumn{3}{|l|}{ Jenis Kelamin } \\
\hline Laki-laki & 36 & 56,2 \\
\hline Perempuan & 28 & 43,8 \\
\hline \multicolumn{3}{|l|}{ Pendidikan Terakhir } \\
\hline Tidak Sekolah & 1 & 1,6 \\
\hline SD/Sederajat & 5 & 7,8 \\
\hline SMP/Sederajat & 10 & 15,6 \\
\hline SMA/Sederajat & 41 & 64,1 \\
\hline Perguruan Tinggi & 7 & 10,9 \\
\hline \multicolumn{3}{|l|}{ Status Pekerjaan } \\
\hline Tidak Bekerja & 10 & 15,6 \\
\hline Buruh & 4 & 6,2 \\
\hline Petani & 1 & 1,6 \\
\hline Wiraswasta & 21 & 32,8 \\
\hline Pegawai Swasta & 3 & 4,7 \\
\hline Pegawai Negeri & 3 & 4,7 \\
\hline Pelajar/Mahasiswa & 10 & 15,6 \\
\hline URT & 4 & 6,2 \\
\hline Lainnya & 8 & 12,5 \\
\hline \multicolumn{3}{|l|}{ Indeks Massa Tubuh } \\
\hline Underweight & 37 & 67,8 \\
\hline Normal & 27 & 42,2 \\
\hline \multicolumn{3}{|l|}{ Riwayat Diabetes } \\
\hline \multicolumn{3}{|l|}{ Melitus } \\
\hline $\mathrm{Ya}$ & 23 & 35,9 \\
\hline Tidak & 41 & 64,1 \\
\hline \multicolumn{3}{|l|}{ Perilaku Merokok } \\
\hline Risiko Tinggi & 18 & 28,1 \\
\hline Risiko Rendah & 46 & 71,9 \\
\hline
\end{tabular}

Sumber: Data Primer, 2020

\section{Analisis Multivariat}

Berdasarkan Tabel 3, didapatkan hasil bahwa semua variabel (umur, Indeks Massa Tubuh, riwayat Diabetes Melitus dan perilaku merokok) yang berhak masuk sebagai kandidat uji multivariat karena nilai $\mathrm{p}<0,25$.

Berdasarkan Tabel 4, pada pemodelan 1 didapatkan hasil variabel Indeks Massa Tubuh dan riwayat Diabetes Melitus memiliki nilai $\mathrm{p}$ value yang paling besar dibandingkan dengan variabel lainnya, sehingga variabel Indeks Massa Tubuh dikeluarkan dari pemodelan karena tidak terjadi perubahan pada nilai Exp B sebesar > $10 \%$.

Berdasarkan Tabel 5, menunjukkan bahwa setelah variabel Indeks Massa Tubuh dikeluarkan dari pemodelan tidak terjadi perubahan pada nilai Exp B $>10 \%$ di variabel riwayat Diabetes Melitus sehingga variabel Indeks Massa Tubuh tetap dikeluarkan dari pemodelan. Pada pemodelan 2, terdapat variabel yang nilainya paling besar yaitu umur $(0,095)$, sehingga variabel tersebut dikeluarkan dari pemodelan.

Berdasarkan Tabel 6, menunjukan bahwa setelah variabel umur dikeluarkan dari pemodelan tidak terjadi perubahan pada nilai Exp $\mathrm{B}>10 \%$ sehingga variabel umur tetap dikeluarkan dari pemodelan. Pada pemodelan 3 yang diuji secara bersamaan, menunjukkan bahwa variabel riwayat Diabetes Melitus $(0,000)$ dan perilaku merokok $(0,050)$ memiliki hubungan signifikan terhadap kejadian TB-DM. 
Sehingga variabel riwayat Diabetes Melitus yang paling berhubungan dengan kejadian TBDM $(\mathrm{p}$ value $=0,000)$ dengan nilai Exp B sebesar 18,294. Artinya seseorang yang memiliki riwayat Diabetes Melitus berisiko mengalami kejadian TB-DM 16,467 kali lebih besar dibandingkan dengan orang yang tidak memiliki riwayat Diabetes Melitus.

Tabel 2. Analisis Faktor Risiko pada Penderita TB-DM dan TB tanpa DM

\begin{tabular}{|c|c|c|c|c|c|c|}
\hline \multirow{3}{*}{ Variabel } & \multicolumn{4}{|c|}{ Kejadian TB-DM } & \multirow{3}{*}{ Total } & \multirow{3}{*}{$\begin{array}{c}\text { OR } \\
\text { (CI 95\%) }\end{array}$} \\
\hline & \multicolumn{2}{|c|}{ Kasus } & \multicolumn{2}{|c|}{ Kontrol } & & \\
\hline & $\mathbf{n}$ & $\%$ & $\mathbf{n}$ & $\%$ & & \\
\hline Umur & & & & & & \\
\hline Risiko Tinggi & 11 & 68,8 & 17 & 35,4 & 28 & 4,012 \\
\hline Risiko Rendah & 5 & 31,2 & 31 & 64,6 & 36 & $(1,195-13,472)$ \\
\hline Indeks Masa Tubuh & & & & & & \\
\hline Risiko Tinggi & 5 & 31,2 & 32 & 66,7 & 37 & $\begin{array}{c}0,227 \\
0670776)\end{array}$ \\
\hline Risiko Rendah & 11 & 68,8 & 16 & 33,3 & 27 & $(0,067-0,776)$ \\
\hline Riwayat Diabetes Melitus & & & & & & \\
\hline Risiko Tinggi & 13 & 81,2 & 10 & 20,8 & 23 & $\begin{array}{c}16,40 / \\
(2018,0202)\end{array}$ \\
\hline Risiko Rendah & 3 & 18,8 & 38 & 79,2 & 41 & $(3,918-69,202)$ \\
\hline Perilaku Merokok & & & & & & \\
\hline Risiko Tinggi & 8 & 50,0 & 10 & 20,8 & 18 & $\begin{array}{c}3,800 \\
(1,142,12,616)\end{array}$ \\
\hline Risiko Rendah & 8 & 50,0 & 38 & 79,2 & 46 & $(1,142-12,646)$ \\
\hline
\end{tabular}

Sumber : Data Primer, 2020

Tabel 3. Nilai Signifikan Masing-masing Variabel pada Uji Multivariat

\begin{tabular}{lc}
\hline \multicolumn{1}{c}{ Variabel } & Sig \\
\hline Umur & 0,025 \\
Indeks Masa Tubuh & 0,017 \\
Riwayat Diabetes Melitus & 0,000 \\
Perilaku Merokok & 0,030 \\
\hline
\end{tabular}

Sumber : Data Primer, 2020

Tabel 4. Hasil Uji Multivariat Model 1

\begin{tabular}{lcccc}
\hline \multicolumn{1}{c}{ Variabel } & Sig. & \multirow{2}{*}{$\operatorname{Exp~(B)~}$} & \multicolumn{2}{c}{$\mathbf{9 5 \%}$ C.I. EXP (B) } \\
\cline { 4 - 5 } & & & Lower & Upper \\
\hline Umur & .153 & 4.084 & .593 & 28.108 \\
Indeks Masa Tubuh & .997 & .000 & .000 &. \\
Riwayat Diabetes Melitus & .997 & $2.670 \mathrm{E} 9$ & .000 & \\
Perilaku Merokok & .040 & 7.516 & 1.096 & 51.559 \\
Constant & .047 & .004 & & \\
\hline Sumber & & &
\end{tabular}

Sumber : Data Primer, 2020 
Tabel 5. Hasil Uji Multivariat Model 2

\begin{tabular}{lcccc}
\hline \multicolumn{1}{c}{ Variabel } & \multirow{2}{*}{ Sig. } & \multirow{2}{*}{$\operatorname{Exp}(\mathbf{B})$} & \multicolumn{2}{c}{ 95\% C.I. EXP (B) } \\
\cline { 5 - 6 } & & & Lower & Upper \\
\hline Umur & .095 & 3.553 & .804 & 15.706 \\
Riwayat Diabetes Melitus & .000 & 17.176 & 3.522 & 83.758 \\
Perilaku Merokok & .056 & 4.657 & .960 & 22.588 \\
Constant & .001 & .001 & & \\
\hline Sumber & & &
\end{tabular}

Sumber : Data Primer, 2020

Tabel 6. Hasil Uji Multivariat Model 3

\begin{tabular}{lcccc}
\hline \multicolumn{1}{c}{ Variabel } & \multirow{2}{*}{ Sig. } & \multirow{2}{*}{$\operatorname{Exp}(\mathbf{B})$} & \multicolumn{2}{c}{$\mathbf{9 5 \%}$ C.I. EXP (B) } \\
\cline { 4 - 5 } & & & Lower & Upper \\
\hline Riwayat Diabetes Melitus & .000 & 18.294 & 3.924 & 85.294 \\
Perilaku Merokok & .050 & 4.626 & 1.003 & 21.340 \\
Constant & .001 & .001 & & \\
\hline
\end{tabular}

Sumber : Data Primer, 2020

\section{PEMBAHASAN}

\section{Umur sebagai Faktor Risiko Kejadian TB- DM}

Umur adalah variabel yang selalu diperhatikan di dalam penyelidikan-penyelidikan epidemiologi. Angka-angka kesakitan maupun kematian di dalam hampir semua keadaan menunjukkan adanya hubungan dengan umur. Penderita TB-DM umumnya terjadi pada umur tua ( $\geq 45$ tahun), hal ini disebabkan karena seseorang yang berumur lanjut lebih rentan untuk terkana infeksi M. tuberculosis. Hal ini disebabkan sistem biologi seseorang mengalami penurunan, yang akan merusak sistem barrier dan mekanisme klirens microbial pada sistem Pernafasan (Fauziah DF dkk, 2016).

Berdasarkan hasil penelitian, menunjukkan bahwa seseorang yang berumur $\geq 45$ tahun berisiko 4,012 kali lebih besar mengalami TB-DM dibandingkan dengan orang yang berumur $<45$ tahun. Hal ini disebebkan karena dengan bertambahnya umur seseorang akan mengalami penuaan sel. Penuaan sel meliputi dua aspek yaitu (1) poliferasi dan diferensiasi sel akhirnya akan berhenti; dan (2) mempertahankan fungsi dasar sel, berhentinya pertumbuhan, namun masih mempertahankan metabolisme. Salah satu faktor perangsang yang dapat menginduksi penuaan sel yaitu stres oksidatif. Stres oksidatif adalah keadaan ketidakseimbangan antara antioksidan protektif (pertahanan antioksidan) dan peningkatan radikal bebas. Dampak dari stres oksidatif ini akan meningkatkan modifikasi lipid, DNA dan protein dalam jaringan sehingga terjadi keadaan hyperglycemia (Suastika K dkk, 2018). 
Walaupun demikian didapatkan 5 orang yang berumur $<45$ tahun tetapi mengalami TBDM. Menurut pengelola program TB di Puskesmas Kamonji, hal ini dapat terjadi karena efek dari pemberian OAT yang dapat meningkatkan kadar gula dalam darah. Sehingga terdapat penderita yang berumur $<45$ tahun dapat mengalami keadaan hyperglycemia.

Penelitian ini sejalan dengan penelitian Dewi et al (2017) di Denpasar yang menyatakan umur diatas 45 tahun merupakan faktor risiko kejadian TB-DM dengan nilai OR 7,47. Hal ini didukung dengan penelitian oleh Tenaye et al (2019) di Kota Diredawa, Etopia yang menyatakan umur $\geq 41$ tahun merupakan faktor risiko TB-DM dengan nilai $\mathrm{OR}=9,95$. Senada dengan penelitian oleh Pin-Hui et al (2016) yang menyatakan umur merupakan faktor risiko dari kejadian TB-DM $(<0.001)$.

Hasil penelitian ini tidak sejalan dengan penelitian Lusiani (2019) yang menyatakan bahwa umur bukan merupakan faktor risiko kejadian TB-DM $(p=1,000)$. Karena dalam penelitiannya menyatakan bahwa sebagian besar terjadi di umur produktif karena penderita memiliki pekerjaan yang memungkinkan untuk berinteraksi dengan banyak orang.

\section{Indeks Massa Tubuh merupakan Faktor Protektif Kejadian TB-DM}

Indeks massa tubuh adalah nilai yang diambil dari perhitungan antara berat badan (BB) dan tinggi badan (TB) seseorang. IMT dipercayai dapat menjadi indikator atau menggambarkan kadar adipositas dalam tubuh seseorang (Purwandari H dkk, 2017).

Berdasarkan hasil penelitian menunjukkan bahwa, seseorang dengan status IMT underweight dapat mengurangi risiko terjadinya TB-DM sebesar $0,227 \quad(22,7 \%)$ daripada seseorang yang memiliki status IMT normal. Hal ini disebabkan karena sebelum mengalami TBDM status IMT responden berada pada kelompok overweight dan mengalami perubahan menjadi IMT normal. Selain itu, menurut pemaparan responden semenjak di diagnosis memiliki penyakit kormorbid, mereka melakukan pengontrolan gula dengan baik dengan rutin meminum OAD dan OAT dan mengatur pola makan yang baik. Menurut Yusnitasari (2015), Diabetes Melitus tipe 2 sering dikaitkan dengan IMT yang relatif tinggi oleh karena itu tidak mengherankan dalam kebanyakan studi penderita TB dengan kormorbid Diabetes Melitus memiliki IMT normal.

Walaupun demikian terdapat 5 orang pada kelompok kasus dan 32 orang pada kelompok kontrol yang memiliki risiko tinggi pada status IMT-nya. Hal ini dikarenakan penderita TB mengalami penurunan nafsu makan sehingga mengakibatkan daya tahan tubuh menurun karena tidak terpenuhinya kebutuhan gizi sehingga seseorang akan lebih mudah terserang penyakit. Menurut Sembiring menyatakan bahwa penyakit tuberkulosis 
menyebabkan gangguan absorbsi gizi sehingga banyak zat gizi yang harusnya bermanfaat namun tidak diserap oleh tubuh, ini yang mengakibatkan tubuh penderita tuberkulosis sangat kekurangan gizi atau underweight dan tidak disokong dengan energi. Keadaan ini yang dapat meningkat seseorang menderita tuberkulosis dan infeksi sekunder lainnya. Penurunan berat badan terjadi karena Mycobacterium tuberculosis akan mengaktifasi makrofag, pengaktifan makrofag ini dapat melalui berbagai perangsangan antara lain (1) fagositosis; (2) kontak reseptor dengan partikel antigen eksogen; (3) akibat dipicu oleh sitokin yang dilepaskan oleh sel T-helper (Th). Setelah mengaktifkan makrofag oleh IFN- $\gamma$ maka akan diproduksinya pirogen endogen IL-1, IL-4,IL-6 (sebagai tanda bahaya apabila tidak terjadi reaksi fagositosis) dan TNF- $\alpha$ yang akan menyebar ke pembuluh darah sistemik dan menembus masuk hematoencephalic barrier dan bereaksi terhadap hipotalamus (Dewi BDN, 2019).

Hasil penelitian ini sejalan dengan penelitian yang dilakukan oleh Yusnitasari (2015) yang mengatakan bahwa status IMT seseorang merupakan faktor protektif $(\mathrm{OR}=0,80)$ terhadap kejadian TB-DM karena rata-rata penderita TB-DM berada pada status gizi normal $\left(18,5 \mathrm{~kg} / \mathrm{m}^{2}-22 \mathrm{~kg} / \mathrm{m}^{2}\right)$. Namun, penelitian ini tidak sejalan dengan penelitian Hoa et al (2018) yang menyatakan bahwa status IMT underweight bukan merupakan faktor risiko kejadian TB-DM ( $p=0,304)$.

\section{Riwayat Diabetes Melitus sebagai Faktor Risiko Kejadian TB-DM}

Keturunan (genetik) merupakan faktor yang telah ada dalam diri manusia yang dibawa sejak lahir, keturunan adalah faktor resiko yang tidak mungkin dihindari Anak yang lahir dari orangtua penderita Diabetes Melitus (DM) akan mempunyai risiko lebih tinggi dibandingkan dengan anak yang lahir dari orang tua bukan penderita Diabetes Melitus. Apabila seseorang yang memiliki riwayat Diabetes Melitus tidak mengatur dietnya dan tidak melakukan berbagai macam upaya pencegahan, maka faktor genetik itu akan berkembang menjadi faktor risiko Diabetes Melitus pada dirinya (Setyawan FEB, 2019).

Hasil analisis uji odd ratio (OR) sebesar 16,467 (3,918-69,202) dengan Confidence Interval (CI) 95\%, karena nilai $\mathrm{OR}>1$ serta nilai lower $(3,918)$ dan upper $(69,202)$ tidak mencakup angka 1, maka riwayat Diabetes Melitus merupakan faktor risiko dalam penelitian ini. Seseorang yang memiliki riwayat Diabetes Melitus berisiko mengalami kejadian TB-DM 16,467 kali lebih besar dibandingkan dengan orang yang tidak memiliki riwayat Diabetes Melitus.

Hal ini dikarenakan sebagian besar responden yang mengalami TB-DM memiliki riwayat penyakit Diabetes Melitus dari Ibu kandung mereka sehingga peluang untuk terkena Diabetes Melitus lebih besar. Selain itu, alasan lainnya yaitu kurang melakukan aktivitas fisik, 
pola makan yang tidak baik, dan mengalami stres akibat pengebotan yang dilakukan. Menurut Setyawan (2019), yang menyatakan bahwa risiko untuk mendapatkan Diabetes Melitus dari ibu lebih besar 10-30\% dari pada ayah dengan Diabetes Melitus. Hal ini dikarenakan penurunan gen sewaktu dalam kandungan lebih besar dari ibu. Jika kedua orang tua memiliki Diabetes Melitus maka risiko untuk menderita Diabetes Melitus sebesar 75\%. Apabila saudara kandung menderita Diabetes Melitus maka risiko untuk menderita Diabetes Melitus maka risiko untuk menderita Diabetes Melitus adalah 10\% dan 90\% jika memiliki saudara kembar identik.

Walaupun demikian, didapatkan 3 responden yang tidak memiliki riwayat Diabetes Melitus namun mengalami TB-DM. Hal ini terjadi karena mereka yang masih kurang untuk menerapkan pola hidup sehat dan mengalami stres akibat dari pengobatan yang mereka jalani. Menurut Purwandari and Susanti (2017) diet yang tepat dapat membantu mengontrol gula darah agar tidak meningkat melebihi nilai ambang batas secara tiba-tiba. Pengaturan pola makan yang tidak baik pada penderita TB-DM akan memperparah keadaan hyperglycemia apabila tidak diseimbangi dengan aktivitas fisik secara teratur. Selain itu, keadaan stres yang dialami oleh penderita TB-DM juga dapat memicu keadaan hyperglycemia. Menurut Badescu (2016), menyatakan bahwa stres lebih umum terjadi pada orang dengan penyakit kormorbid. Selain itu, dengan adanya stres akan mendorong sekresi hormon stres (epinefrin, glukagon, kortisol, dan hormon pertumbuhan) yang berdampak pada meningkatnya kadar gula darah hingga 200 mg/dl (Sasmita HY, 2017).

Penelitian ini sejalan dengan penelitian yang dilakukan oleh Sharma et al (2019) di Nepal yang menyatakan bahwa riwayat Diabetes Melitus dalam keluarga merupakan faktor risiko kejadian TB-DM dengan nilai OR $=4,096$. Hal ini didukung dengan penelitian oleh Tenaye et al (2019) di Kota Diredawa, Etopia yang menyatakan bahwa riwayat Diabetes Melitus merupakan faktor risiko dari kejadian TB-DM dengan nilai $\mathrm{OR}=3,14$. Senada dengan penelitian yang dilakukan oleh Hoa et al (2018) di Vietnam yang menyatakan bahwa bahwa riwayat Diabetes Melitus merupakan faktor risiko kejadian TB-DM dengan nilai $\mathrm{OR}=2,71$.

Penelitian ini tidak sejalan dengan penelitian yang dilakukan oleh Rohman (2018) ang menyatakan bahwa riwayat Diabetes Melitus bukan faktor risiko terhadap kejadian TB-DM $(p=0,065)$ dikarenakan jumlah sampel kasus yang menderita Diabetes Melitus disebabkan karena pola hidup yang tidak sehat serta masih kurangnya kesadaran masyarakat di Kabupaten Kulon Progo untuk melakukan screening bagi yang memiliki riwayat Diabetes Melitus.

\section{Perilaku Merokok sebagai Faktor Risiko Kejadian TB-DM}

Perilaku merokok merupakan faktor risiko 
penting untuk terjadinya penyakit kardiovaskular serta penyebab utama lain dari kematian di seluruh dunia. Studi penelitian menunjukkan hubungan merokok dengan kejadian TB pertama kali dilaporkan pada tahun 1918 (Wijaya, 2015).

Dari hasil analisis diperoleh nilai $\mathrm{OR}=$ 3,800 (1,142-12,646) dengan Confidence Interval (CI) 95\%, maka perilaku merokok merupakan faktor risiko dalam penelitian ini. Berdasarkan wawancara dengan responden, terdapat responden yang mengalami TB-DM dan memiliki perilaku merokok risiko tinggi sebanyak 8 orang $(50,0 \%)$ dan responden yang mengalami TB tanpa Diabetes Melitus memiliki perilaku merokok risiko tinggi sebanyak 10 orang (20,8\%). Hal ini dikarenakan, sebagian besar responden yang pernah merokok dan mengalami TB-DM ditemukan pada kelompok laki-laki. Menurut Purwandari et al (2020) dalam penelitiannya yang menyatakan bahwa terdapat perbedaan peran antara peran laki-laki dan perempuan dalam perilaku merokok. Lakilaki yang berperilaku merokok dapat memberikan kesan macho, berani dan pria sejati sedangkan perempuan lebih mendapatkan citra negatif di masyarakat yaitu nakal dan jauh dari kesan feminism.

Selain itu, lama merokok merupakan faktor risiko terhadap masuknya Mycobacterium tuberculosis karena paparan kronis nikotin dalam asap rokok dapat merusak makrofag alveolar paru-paru sehingga mempengaruhi limfosit sel $\mathrm{T}$ yang berfungsi membedakan jenis pathogen dan berfungsi dalam meningkatkan kekebalan setiap kali tubuh terpapar oleh pathogen. Selain itu, paparan yang cukup lama dari nikotin mengakibatkan penurunan sekresi insulin (Sasmita HY, 2017).

Walaupun demikian, berasarkan wawancara dengan responden, didapatkan hasil terdapat 8 orang yang memiliki perilaku merokok yang risiko rendah tetapi mengalami TB-DM. Hal ini karena penyebab TB-DM sangat kompleks. Kejadian TB-DM tidak disebabkan oleh faktor perilaku merokok yang berisiko. Menurut Dewi et al (2017) perilaku merokok yang baik tidak menjamin seseorang tidak terkena TB-DM, karena terdapat banyak faktor risiko yang bisa seseorang terkena TBDM seperti terpaparnya bakteri M.tb, riwayat Diabetes Melitus, gaya hidup yang tidak sehat, faktor lingkungan dan sebagainya.

Penelitian ini sejalan dengan penelitian yang dilakukan oleh Sharma et al (2019) di Nepal yang menyatakan bahwa perilaku merokok merupakan faktor risiko kejadian TB$\mathrm{DM}$ dengan nilai $\mathrm{OR}=2,247$. Hal ini didukung dengan penelitian oleh Dewi et al (2017) di Denpasar yang menyatakan bahwa bahwa perilaku merokok merupakan faktor risiko kejadian TB-DM dengan nilai $\mathrm{OR}=2,80$.

Penelitian ini tidak sejalan dengan penelitian yang dilakukan oleh Leal, Meciel and Cade (2019) di Brazil menyatakan bahwa perilaku merokok bukan faktor risiko dari kejadian TB-DM $(\mathrm{p}=0,060)$. Hal ini dikarenakan 
jumlah kelompok kasus yang sebagian besar perempuan yang tidak memiliki perilaku merokok

\section{Determinan TB-DM pada Penderita TB}

Berdasarkan uji multivariat (Tabel 6), menunjukkan bahwa variabel riwayat Diabetes Melitus $(0,000)$ dan perilaku merokok $(0,050)$ memiliki hubungan signifikan terhadap kejadian TB-DM. Sehingga variabel riwayat Diabetes Melitus yang paling berhubungan dengan kejadian TB-DM ( $p$ value $=0,000)$ dengan nilai Exp B sebesar 18,294. Artinya seseorang yang memiliki riwayat Diabetes Melitus berisiko mengalami kejadian TB-DM 16,467 kali lebih besar dibandingkan dengan orang yang tidak memiliki riwayat Diabetes Melitus.

\section{KESIMPULAN DAN SARAN}

Adapun kesimpulan dari penelitian ini adalah umur, riwayat Diabetes Melitus dan perilaku merokok merupakan faktor risiko kejadian TB-DM sedangkan indeks massa tubuh merupakan faktor protektif dalam penelitian ini dan yang merupakan determinan TB-DM pada penderita TB di wilayah kerja Puskesmas Kamonji adalah riwayat Diabetes Melitus.

Perlu dilakukannya screening PTM secara teratur bagi penderita TB-DM maupun TB tanpa Diabetes Melitus serta melakukan aktivitas fisik, mengatur pola makan, mengontrol stres dan meningkatkan kesadaran mengenai perilaku merokok yang agar tidak terjadi berbagaimacam komplikasi.

\section{DAFTAR PUSTAKA}

Chritianto A. Paradigma Baru Tuberkulosis pada Era Sustainable Development Goals (SDGs) dan Implikasinya di Indonesia. CDK. 2018;45(1).

WHO. The End TB Strategy. Geneva; 2015.

WHO. Global Tuberculosis Report 2019. Geneva; 2019.

Kementerian Kesehatan RI. Profil Kesehatan Indonesia 2018. Jakarta: Kementerian Kesehatan RI; 2019.

Dinas Kesehatan Sulteng. Profil Kesehatan Provinsi Sulawesi Tengah Tahun 2018. Sulawesi Tengah: Dinas Kesehatan Sulawesi Tengah; 2019.

Dinas Kesehatan Kota Palu. Profil Dinas Kesehatan Kota Palu Tahun 2017. In Palu; 2018.

Sembiring SPK. Indonesia Bebas Tuberkulosis. Awahita R, editor. Bandung: CV Jejak; 2019.

Prameyllawati DM, Saraswati LD. Faktor Risiko Ketidakikutsertaan Skrining Tuberkulosis (Studi pada Penderita Diabetes Mellitus di Puskesmas Imogiri 1 Bantul). J Kesehat Masy. 2019;7(4).

Kementerian Kesehatan RI. Petunjuk Teknis Penemuan Pasien TB-DM di Fasilitas Kesehatan Rujukan Tingkat Lanjut. Jakarta: Kemenkes RI Dirjen P2PL; 2015.

Hoa NB, Phuc PD, Hien NT, Hoa VQ, Thuong $\mathrm{PH}$, Anh PT, et al. Prevalence and Associated Factors of Diabetes Mellitus Among Tuberculosis Patients in Hanoi, Vietnam. BMC Infect Dis. 2018;18(603):1-9.

Rohman H. Kasus Tuberkulosis dengan Riwayat Diabetes Mellitus di Wilayah Prevalensi Tinggi Diabetes Mellitus. J Manaj Inf 
Kesehat Indones. 2018;6(2).

Fauziah DF, Basyar M, Manaf A. Insidensi Tuberkulosis Paru pada Pasien Diabetes Mellitus Tipe 2 di Ruang Rawat Inap Penyakit Dalam RSUP Dr. Djamil Padang. J Kesehat Andalas. 2016;5(2).

Suastika K. Penaan, Diabetes dan Insulin. Jakarta: Gramedia Pustaka Utama; 2018.

Setyawati A, Hartini E. Dasar Ilmu Gizi Kesehatan Masyarakat. Yogyakarta: Deepublish; 2018.

Yusnitasari AS. Kormobiditas Diabetes Mellitus Terhadapa Manifestasi Klinik dan Kuliatas Hidup Pada Penderita Tuberkulosis Paru. J MKMI. 2015;11(2):86-91.

Dewi BDN. Diabetes Mellitus \& Infeksi Tuberkulosis - Diagnosis dan Pendekatan Terapi. Yogyakarta: Andi Offset; 2019.

Setyawan FEB. Pendekatan Pelayanan Kesehatan Dokter Keluarga (Pendekatan Holistik Komprehensif). Surabaya: Zifatama Jawara; 2019.
Purwandari H, Susanti SN. Hubungan Kepatuhan Diet Dengan Kualitas Hidup pada Penderita DM di Poli Penyakit Dalam RSUD Kertosono. J Ilm Kesehat Str. 2017;6(2):19-22.

Badescu S. The Association between Diabetes Mellitus and Depression. J Med Life. 2016;9(4).

Sasmita HY. Prevalensi dan Faktor Risiko Diabetes Melitus pada Pasien Tuberkulosis di Puskesmas Patrang Kabupaten Jember Tahun 2017. Skripsi. Universitas Jember; 2017.

Wijaya. Tuberkulosis Paru pada Penderita Diabetes Mellitus. Kalbe Med. 2015;42(6).

Purwandari E, Pubianti E, Sofiana M, Nugroho MD, Freddy. Terapi Berhenti Merokok dengn Spritual Emotional Freedom Technique (SEFT). J War LPM. 2020;23(2):84-93.

Dewi. Menu Sehat 30 Hari untuk Mencegah dan Mengatasi Diabetes. Yogyakarta: Nuha Medika; 